\title{
The Awareness on Patients' Rights: Results of A Survey on Healthcare Givers
}

Hasta Hakları Konusunda Farkındalık:

\author{
Sağlık Çalışanları Arasındaki Bir Çalışmanın Sonuçları
}

\author{
Hasan Hüseyin Eker', Halime Aydın², Zarif Karakuş² , Turgut Şahinoz', \\ Aclan Özder ${ }^{3}$, Mahmut Tokaç ${ }^{4}$, Mustafa Öncel ${ }^{2}$ \\ 'Gümüşhane Üniversitesi, Sağlık Meslek Yüksek Okulu, Gümüşhane \\ ${ }^{2}$ Kartal Eğitim ve Araştırma Hastanesi, Genel Cerrahi Kliniği, İstanbul \\ ${ }^{3}$ Afyon Kocatepe Üniversitesi Tıp Fakültesi, Aile Hekimliği Anabilim Dalı, Afyonkarahisar \\ ${ }^{4}$ Başakşehir Devlet Hastanesi, İstanbul
}

\begin{abstract}
Objective: To assess the status and the factors that may affect the awareness of health workers on patients' rights and related violation reports.

Materials and Methods: The participants were composed of healthcare givers working in a level-3 governmental hospital and filled a survey form based upon the "Code of Patient Rights". Demographics and interviewer-related factors, their reflections on being well-informed and rule violations on patients' rights were evaluated.

Results: The average sum point was $67.9 \pm 11.2$ among 263 subjects $212(80.6 \%)$ females; mean $[ \pm S D]$ age was $34.2 \pm 8.8 .149(59.1 \%)$ participants believed that they were well-informed, however, they got comparable points and similar violation reports with others ( $p>0.05)$ Males and physicians were reported more commonly for rule violations, and those who had violation reports $(n=49,19.7 \%)$, received less points in Chapters 1, 3, 4 and total sums $(p<0.05)$

Conclusion: Educations are better to be continued among all workers without any exceptions, particularly for physicians and males who have more violation reports, since these reports are less common among the healthcare workers who are well-informed.
\end{abstract}

Keywords: healthcare workers, patients' rights, medical intervention, violation report

Aplication: 26.10.2011 Accepted: 28.10.2011
Özet

Amaç: Bu çalışmada sağlık çalışanlarının hasta hakları ve ilgili ihlal raporları hakkındaki farkındalıklarının ve bunu etkileyen faktörlerin değerlendirilmesi amaçlanmıştır.

Gereç ve Yöntem: 3. basamak sağlık hizmeti veren devlet hastanelerinde görev yapan sağlık çalışanlarında "Hasta Hakları Yönetmeliği"ni temel alan bir çalışma formu oluşturuldu. Bu çalışmada sağlık çalışanlarının Demografik özellikleri ile hasta haklarıyla ilgili bilgi düzeyleri ve hasta haklarıyla ilgili kural ihlalleri hakkındaki durumlar değerlendirildi.

Bulgular: Araştırmaya katılan 263 katılımcının 212'si (\% 80.6) kadın, yaş ortalamaları $34.2 \pm 8.8$ ve hasta hakları ile ilgili aldıkları toplam puan

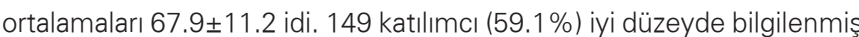
olduklarına inanıyorlardı, fakat diğerleriyle kıyaslandığında benzer ihlal raporları vardı $(p>0.05)$. Erkekler ve hekimlerin daha fazla șiddete maruz kaldıkları ve ihlal raporu düzenledikleri saptandı ( $n=49,19.7 \%)$, bunlar bilgi düzeyi olarak Bölüm 1, 3, 4'de ve toplamda daha az puan almışlardır $(p<0.05)$.

Sonuç: lyi düzeyde bilgilenmiş olan sağlık çalışanlarında ihlal raporlaması daha az bulunduğu için özellikle daha fazla ihlal rapor eden erkek çalışanlar ve hekimler olmak üzere, istisnasız olarak tüm çalışanlar arasında eğitimlerin devam etmesi iyi olacaktır.

Anahtar Kelimeler: sağlık çalışanları, hasta hakları, tıbbi girişim, ihlal raporu

Başvuru Tarihi: 26.10.2011 Kabul Tarihi: 28.10.2011 


\section{Introduction}

The term "Patient Rights" refers to rights, of individuals in need of medical services, that are inborn of being a human and that are guaranteed by Constitution of Turkish Republic, international truces, laws and other legislations and regulations. ${ }^{1}$ Up to now, many charters/declarations have been prepared to define the fundamental principles of physician-patient interactions, such as Nurnberg Rules (1947), Helsinki Declaration (1963), European Council Recommendation Ordinance on Subject of Patient Rights and Death (1976), European Economic Community Hospital Committee - Declaration of Rights of Inpatients (1979), Lisbon Declaration of Patient Rights (1981), Declaration of Improving Patient Rights in Europa - Amsterdam (1994).2, 3

In Lisbon declaration related to topic in 1981, physicians' approaches to the patients have been described and the rights of patients to choose physician, to consent or refuse treatment modality, the confidentiality of any kind of information about the patient, the right to consent or refuse moral consolation have been put into script for the very first time. ${ }^{4,5}$ In 1994 Declaration of Improving Patient Rights in Europa - Amsterdam; ethical principles to promote health care policies that would arrange the right of being healthy as the right to reach health care service as far as any individual needed have been brought under scope, also by giving importance to human rights and by considering that physician-patient relationship would occur in an health system. This declaration has been accepted in the meeting prepared by European Bureau of World Health Organization in 1994. World Physicians Union has reviewed Lisbon Declaration expanding and updating it as well in Bali in September 1995. According to this update, the patient has the right to receive qualified medical care, to choose physician/hospital, to determine his/her own destiny, to be informed, confidentiality, to receive education on health topics, to protect his/ her dignity, to get religious help. ${ }^{6}$

After Lisbon declaration every country has set legal regulations about patient rights that are also appropriate for their own legal system. As for our country, the legal processes have been described in "Ministry of Health Patient Rights Regulation" published in 01.08.1998 and "Regulation of Patient Rights Applications in Health Facilities" published by Ministry ofHealth in 10.15.2003.1,7 Regulation of Patient Rights by Ministry of Health is a very widely prepared legal text on patient rights. In this regulation, patient rights have been addressed in issues under the topics Benefitting Health Care Services, Having Information about State of Health, Respect for Confidentiality, and Taking Consent of Patient in Medical Intervention, Medical Researches and Other Rights. ${ }^{1,5}$ The actual legal regulations on patient rights burden all health care givers, especially the physicians; , with important tasks and responsibilities and when these can not be carried out this may sometimes cause judicial and legal problems. It is critically important that these responsibilities are well known and applied to improve quality of service granted and to prevent patient rights violations in legal aspect and problems related with them. ${ }^{5}$

It has been shown that patients' satisfaction may improve when healthcare givers follow the rules of patients' rights during the treatment period. ${ }^{5}$ It has been rarely studied whether or not who believe they are sufficient on the subject are adequately educated, but may be speculated that healthcare givers generally believe that they are well-informed on patients' rights, which may be an important limitation in improving the quality of care. On the other hand, patients' satisfaction may reflect the incidence of violation reports on patients' rights. However, little is known on the relationship between healthcare givers' knowledge on the subject, and the frequency of the violation reports. Kartal Education and Research Hospital is one of the largest governmental health centers working with a high patient volume at the Anatolian side of Istanbul, and an analyze on running health workers in this hospital may reflect all level 3 hospitals over Turkey. So, this study aims to assess the awareness of the healthcare givers on patients' rights in a level 3 governmental hospital in Istanbul, Turkey, and analyze the relationship between their thoughts of capability and their knowledge on the subject. In addition, 
current study also evaluates the rate of being reported for a complaint, and its relation with the qualification on the patients' rights.

\section{Materials and Methods}

A cross-sectional study was carried out on healthcare givers working at a level 3 hospital (Kartal Education and Research Hospital) between December 2009 and January 2010. The design and content of the study were approved by the local Institutional Board Commity of Kartal Education and Research Hospital. A face-to-face survey, which was generated from the 'Code of Patient Rights' that had been published in Official Journal of Turkish Republic on 01.08.1998 with number 23,420, was used among those who had accepted to participate. ${ }^{1,7-9}$ The questionnaire had two sections. The first part of survey form consisted of personal information including demographics, department (surgery or medicine), occupation (physician, nurse, other employments), duration of healthworking career $(<5,5$ to 10,10 to $15,>15$ years), working station (emergency department, policlinics, wards, operation room [OR] or intensive care unit [ICU] and other locations), belief of being well-informed on patients' rights (sufficient, not sufficient) and whether or not being reported for a rule violation related to patients' rights during the last year (yes or no). The second part had 5 chapters that included 5 questions in each, in order to detect the level of knowledge about benefiting health care services in chapter 1 , getting information about the state of health in chapter 2, protection of patients' information in chapter 3 , patient's will in medical intervention in chapter 4 and consent in medical researches in chapter 5 (Table 1). Every right answer would deserve 4 points each, reaching a sum of 100 points in total. Participants were free to skip over the confidential (belief of being sufficient and report of rule violation) questions in the first part of the survey, however if someone refused to respond any of the questions in second part of the questionnaire, the answer was accepted to be wrong. The particients were divided into 2 groups according to their belief of being sufficient on the subject, and records were compared within the groups. In addition, informati- ve or comparative data were also discussed particularly on the rule violation reports.

Statistics: The data was evaluated with SPSS 11.5 package program. Student's t test, ANOVA, Turkey's or chi-square tests were used for the comparisons and a $p$ value less than 0.05 was considered to be significant.

\section{Results}

A total of 263 subjects (212 [80.6\%] females, 33.2 \pm 10.9 years old) approved to participate to the study and answered the questions. The participants were working at surgical $(n=148,56.3 \%)$ or internal medicine ( $n=115$, $47.7 \%$ ) departments, as physicians ( $n=54,20.5 \%)$, nurses $(n=186,70.7 \%)$ or other employees $(n=23,8.7 \%)$ for less than $5(n=72,27.4 \%), 5$ to $10(n=42,16.0 \%), 10$ to $15(n=43,16.3 \%)$, or more than $15(n=106,40.3 \%)$ years. The working stations were emergency department $(n=38,14.4 \%)$, policlinics $(n=119,45.2 \%)$, wards $(n=49,18.6 \%)$, OR or ICU $(n=24,9.1 \%)$ and other locations $(n=33,12.5 \%)$. Participants were free to skip questions related to their belief of being sufficient on and being reported for a rule violation related to patients' rights during the last year, and 11 (4.2\%) and 14 (5.3\%) interviewee refused to answer associated questions, respectively. Among the remaining participants, 149 (59.1\%) stated that he/she believed to be competent and 49 $(19.7 \%)$ declared being reported for a rule violation.

The questionnaire included 25 questions in 5 chapters. Participants had a mean $( \pm S D)$ point of $68.0 \pm 11.2$, and the most and the least points were taken from the answers to questions of chapters $1(15.3 \pm 3.8)$ and 4 $(15.3 \pm 4.2)$, and chapter $3(11.1 \pm 3.4)$, respectively. The overall and pair-wise comparisons of the points taken from the chapters revealed that chapter 1 and 4 were significantly best known and chapter 3 was the least known parts ( $p<0.05$ for all comparisons) (Table 1). Q16 $(98.0 \%)$ and $\mathrm{Q} 12$ (4.7\%) were the most and least commonly right answered questions, respectively (Table 1). The relationships between the participant related parameters and taken points from each chapter and in total 
Table 1: The Participants were Asked 25 Questions in 5 Chapters Based on "Code of Patient Rights" was Published in Official Journal of Turkish Republic in Order to Evaluated Their Knowledge on Patients' Rights. The Rate of Right Answers to the Questions and Points Taken from the Chapters were also Presented.

\section{Chapter 1: Questions on the Right of Benefitting from Health Services}

01: All healthcare facilities and institutions are obliged to deploy staff who has the quality and credentials for giving accurate and sufficient information for informing the patient

02: Those belonging to any social security system but purposely avoiding referral chain have to meet the difference in payment on any condition.

03: The information on serving and about to serve physicians' and other staff's identities, occupations and titles has to be given to patient on demand.

Q4: The patients do not have the right to choose staff, change the physician or ask for consultation.

05: No life can be terminated whether it be the patient's or someone else's will.

\section{Chapter 2: Information about State of Health and Related Questions}

06: The patients have the right to ask for information both verbally and written as well.

07: The patients can demand all current medical records about their diseases.

08: It is not appropriate to conceal the diagnosis from the patient.

09: The patient may ask for information about state of health given to him/her or family members and relatives.

010: The patients may ask for completion of defects in files on their medical records.

Chapter 3: Questions on Protecting Patient Information

011: It is primary to respect for patient's confidentiality. Confidentiality can be removed only in case of death.

012: No medical intervention can be performed on the patient without getting his/her consent.

013: The information gathered while giving medical service can not be revealed on any condition other than those legally permitted or obliged.

014: The information on patient's identity can not be revealed in activities done with reserch and educational purposes.

015: The right of the patient to have presence of any of his/her relatives during the examination on his/her demand can not be deprived in any way.

\section{Chapter 4: Questions on Patient's Will on Medical Intervention}

016: Patient's consent is needed for medical intervention.

017: The consent can not be retracted after beginning of therapy

018: The patient refusing therapy does not have the right to demand help for medical treatment from the same institution.

019: No organ or tissue can be taken from patients younger than 18 years of age and from those younger than age of legal discretion.

020: It is sufficient to have consent from mother in married couples in case of sterilization or termination of pregnancies.

\section{Chapter 5: Questions on Patient's Consent for Medical Research}

021: Nobody can be subject to medical intervention for experimental, research or educational purposes without consent of Ministry of Health and the patient himself/herself

Q22: If the potential damage to the subject can not be predicted, this can not be topic of research.

Q23: In clinical research, the study can be initiated right after getting verbal consent.

024: In trials in which previously permitted or licensed drugs are to be used the consent of Ministry of Health is not essential

Q25: Clinical research can be conducted in sites determined by regulations.

The Rate of Right Answers to the Questions and Points Taken from the Chapters

\begin{tabular}{|c|c|c|c|c|c|c|c|c|c|}
\hline Question & True (\%) & Question & True (\%) & Question & True (\%) & Question & True (\%) & Question & True (\%) \\
\hline 01 & 95.8 & 06 & 96.6 & 011 & 72.3 & 016 & 98.0 & 021 & 5.1 \\
\hline 02 & 37.1 & 07 & 83.5 & 012 & 4.7 & 017 & 61.5 & 022 & 88.0 \\
\hline 03 & 88.2 & 08 & 9.3 & 013 & 85.7 & 018 & 81.6 & 023 & 89.5 \\
\hline 04 & 71.0 & 09 & 80.5 & 014 & 95.7 & 019 & 64.7 & 024 & 60.9 \\
\hline 05 & 93.5 & 010 & 72.6 & 015 & 28.5 & 020 & 87.5 & 025 & 89.2 \\
\hline Chapter1 & Points & Chapter2 & Points & Chapter3 & Points & Chapter4 & Points & Chapter5 & Points \\
\hline \multicolumn{2}{|c|}{$13.5 \pm 3.5$} & \multicolumn{2}{|c|}{$11.1 \pm 3.4$} & $15.3 \pm 4.7$ & & $12.8 \pm 4.2$ \\
\hline
\end{tabular}

(The overall comparison of the points from the chapters with ANOVA test revealed a $p$ value of $p<0.001$. The pair-wise comparisons calculated with Turkey's test are as follows: $p<0.001$ for chapters 1 vs $2 ; p<0.001$ for chapters 1 vs $3 ; p=1.0$ for chapters 1 vs $4 ; p<0.001$ for chapters 1 vs $5 ; p<0.001$ for chapters 2 vs 3 ; $p<0.001$ for chapters 2 vs $4 ; p=0.21$ for chapters 2 vs $5 ; p<0.001$ for chapters 3 vs $4 ; p<0.001$ for chapters 3 vs 5 ; and $p<0.001$ for chapters 4 vs 5 ) 
Table 2: The Associations between the Participant Related Parameters, the Belief of Being Well-Informed and Having Reported for a Rule Violation Related to Patients' Rights with Taken Points from Each Chapter and in Total

\begin{tabular}{|c|c|c|c|c|c|c|c|c|c|c|c|c|}
\hline \multirow[t]{2}{*}{ Question } & \multicolumn{2}{|c|}{ Chapter 1} & \multicolumn{2}{|c|}{ Chapter 2} & \multicolumn{2}{|c|}{ Chapter 3} & \multicolumn{2}{|c|}{ Chapter 4} & \multicolumn{2}{|c|}{ Chapter 5} & \multicolumn{2}{|l|}{ Total } \\
\hline & Points & $P$ & Points & $\mathrm{P}$ & Points & $\mathrm{P}$ & Points & $P$ & Points & $P$ & Points & $\mathrm{P}$ \\
\hline \multicolumn{13}{|l|}{ Gender (n=263) } \\
\hline Male $(n=51)(19.4 \%)$ & $14.8 \pm 4.3$ & $0.352^{*}$ & $13.3 \pm 4.0$ & $0.645^{*}$ & $11.7 \pm 3.8$ & $0.179^{*}$ & $14.9 \pm 4.1$ & $0.523^{*}$ & $12.5 \pm 5.3$ & $0.585^{*}$ & $67.2 \pm 12.7$ & $0.593^{*}$ \\
\hline \multicolumn{13}{|l|}{ Age $(n=263)$} \\
\hline \multicolumn{13}{|l|}{ Department (n=263) } \\
\hline Surgical $(n=148)(56.3 \%)$ & $15.0 \pm 4.0$ & \multirow{2}{*}{$0.293^{*}$} & $13.4 \pm 3.4$ & \multirow{2}{*}{$0.586^{*}$} & $11.0 \pm 3.2$ & \multirow{2}{*}{$0.728^{*}$} & $15.4 \pm 4.7$ & \multirow{2}{*}{$0.570^{*}$} & $12.6 \pm 4.2$ & \multirow{2}{*}{$0.626^{*}$} & $67.6 \pm 11.0$ & \\
\hline Medical $(n=115)(43.7 \%)$ & $15.4 \pm 3.4$ & & $13.7 \pm 3.6$ & & $11.2 \pm 3.4$ & & $15.1 \pm 4.9$ & & $12.9 \pm 4.2$ & & $69.1 \pm 9.0$ & 0.003 \\
\hline Working station (n=263) & & & & & & & & & & & & \\
\hline OR or ICU $(n=24)(9.1 \%)$ & $13.2 \pm 4.1$ & & $14.0 \pm 2.9$ & & $12.0 \pm 2.0$ & & $15.8 \pm 5.8$ & & $13.5 \pm 5.1$ & & $68.5 \pm 13.6$ & \\
\hline Others $(n=33)(12.5 \%)$ & $16.2 \pm 2.4$ & & $13.6 \pm 3.4$ & & $11 . \pm 3.2$ & & $16.0 \pm 3.9$ & & $12.0 \pm 3.3$ & & $68.8 \pm 8.3$ & \\
\hline Occupation (n=263) & & & & & & & & & & & & \\
\hline Physician (n=54) (20.5\%) & $14.8 \pm 4.0$ & & $13.8 \pm 3.5$ & & $11.4 \pm 3.7$ & & $15.2 \pm 5.0$ & & $13.0 \pm 4.9$ & & $68.3 \pm 2.8$ & \\
\hline Nurse $(n=185)(70.3 \%)$ & $15.5 \pm 3.7$ & $0.446 \dagger$ & $13.4 \pm 3.4$ & & $11.0 \pm 3.2$ & $0.511 \dagger$ & $15.0 \pm 4.7$ & $0.120 \dagger$ & $12.6 \pm 4.1$ & $0.706 \dagger$ & $67.5 \pm 10.8$ & $0.369+$ \\
\hline Other $(n=24)(9.1 \%)$ & $14.8 \pm 4.4$ & & $14.1 \pm 4.2$ & & $11.6 \pm 3.4$ & & $17.2 \pm 4.4$ & & $13.2 \pm 3.7$ & & $71.0 \pm 10.0$ & \\
\hline $\begin{array}{l}\text { Duration of Occupation (in years) } \\
(\mathrm{n}=263)\end{array}$ & & & & & & & & & & & & \\
\hline$<5(n=72)(27.3 \%)$ & $15.3 \pm 4.2$ & & $14.3 \pm 3.1$ & & $11.0 \pm 3.7$ & & $15.3 \pm 4.7$ & & $12.5 \pm 4.7$ & & $68.4 \pm 11.3$ & \\
\hline Rule Violation ( $\mathrm{n}=249$ ) & & & & & & & & & & & & \\
\hline I have been reported $(n=49)(19.7 \%)$ & $13.9 \pm 4.4$ & & $13.6 \pm 3.8$ & & $10.0 \pm 4.0$ & & $13.5 \pm 6.0$ & & $12.1 \pm 5.1$ & & $62.9 \pm 14.2$ & \\
\hline $\begin{array}{l}\text { I have not been reported }(n=200) \\
(80.3 \%)\end{array}$ & $15.7 \pm 3.6$ & $0.011^{*}$ & $13.5 \pm 3.5$ & $0.815^{*}$ & $11.4 \pm 3.1$ & $0.026^{*}$ & $15.9 \pm 4.1$ & $0.009^{*}$ & $13.2 \pm 3.7$ & $0.100^{*}$ & $69.7 \pm 9.6$ & $0.002^{*}$ \\
\hline
\end{tabular}

(ER: Emergency room, OR: Operation room, ICU: Intensive care unit)

* Student's t test

†ANOVA

‡Pair-wise comparisons calculated with Turkey's test for working station: $p=0.9$ for ER vs Policlinics; $p=0.951$ for ER vs Ward; $p=0.099$ for ER vs OR or ICU; $p=0.945$ for ER vs Others; $p=0.320$ for Policlinics vs Ward; $p=0.260$ for Policlinics vs OR or ICU; $p=0.404$ for Policlinics vs Others; $p=0.013$ for Ward vs OR or ICU; $\mathrm{p}>0.999$ for Ward vs Others; and $\mathrm{p}=0.02$ for OR or ICU vs Others

( Pair-wise comparisons calculated with Turkey's test for duration of occupation (in years): $p=0.676$ for $<5$ vs $5-10$; $p=0.986$ for $<5$ vs $10-15$; $p=0.033$ for $<5$ vs $>15$; $p=0.898$ for $5-10$ vs $10-15 ; p=0.690$ for $5-10$ vs $>15$; and $p=0.212$ for $10-15$ vs $>15$. 
Table 3: The Relationship between the Evaluated parameters and the Answers of the Subjects on Whether or Not They Believe That They Are Well-Informed in Patients' Rights.

\begin{tabular}{|c|c|c|c|c|}
\hline & $\begin{array}{l}\text { Believe to Be Sufficient } \\
\qquad(\mathrm{n}=252)\end{array}$ & Sufficient (n=149) & Not Sufficient (n=103) & $P$ \\
\hline \multirow{2}{*}{ Gender } & Female $(\mathrm{n}=202)(\%)$ & $119(58.9)$ & $83(41.1)$ & \multirow{2}{*}{$0.1^{*}$} \\
\hline & Male $(n=50)(\%)$ & $30(60)$ & $20(40)$ & \\
\hline \multirow{2}{*}{ Age } & $<35(n=143)(\%)$ & $80(55.9)$ & $63(44.1)$ & \multirow{2}{*}{$0.147^{*}$} \\
\hline & $>35(n=109)(\%)$ & $69(63.3)$ & $40(36.7)$ & \\
\hline \multirow{2}{*}{ Department } & Surgery $(n=141)(\%)$ & $80(56.7)$ & $61(43.3)$ & \multirow{2}{*}{$0.439^{*}$} \\
\hline & Medicine (n=111) (\%) & $69(62.2)$ & $42(37.8)$ & \\
\hline \multirow{5}{*}{ Working Station } & ER $(n=34)(\%)$ & $22(64.7)$ & $12(35.3)$ & \multirow{5}{*}{$0.014^{*}$} \\
\hline & Policlinics (n=115) (\%) & $76(66.1)$ & 39 (33.9) & \\
\hline & Ward $(n=49)(\%)$ & 30 (61.2) & 19 (38.8) & \\
\hline & OR or ICU $(n=24)(\%)$ & $8(33.3)$ & $16(66.7)$ & \\
\hline & Other $(n=30)(\%)$ & $13(43.3)$ & $17(56.7)$ & \\
\hline \multirow{3}{*}{ Occupation } & Physician (n=53) (\%) & $29(54.7)$ & $24(45.3)$ & \multirow{3}{*}{$0.070^{*}$} \\
\hline & Nurse $(n=178)(\%)$ & $112(62.9)$ & $66(37.1)$ & \\
\hline & Other $(n=21)(\%)$ & $8(38.1)$ & $13(61.9)$ & \\
\hline \multirow{2}{*}{ Duration of Occupation } & $<5(\mathrm{n}=69)(\%)$ & $38(55.1)$ & $31(44.9)$ & \multirow{2}{*}{$0.079^{*}$} \\
\hline & $5-10(n=40)(\%)$ & $26(65)$ & $14(35.0)$ & \\
\hline \multirow{2}{*}{ (in years) } & $10-15(n=41)(\%)$ & $18(43.9)$ & $23(56.1)$ & \multirow{4}{*}{$0.348^{*}$} \\
\hline & $>15(n=102)(\%)$ & $67(65.7)$ & 35 (34.3) & \\
\hline \multirow{2}{*}{ Reported Due to a Rule Violation } & Yes $(n=48)(\%)$ & 31.(64.6) & $17(35.4)$ & \\
\hline & No $(n=196)(\%)$ & $112(57.1)$ & $84(42.9)$ & \\
\hline
\end{tabular}

(ER: Emergency room, OR: Operation room, ICU: Intensive care unit)

* Chi-square test

were assessed (Table 2). Evaluated parameters were not significant in the awareness of the patients' rights except 3 comparisons: working station, and age and duration of occupation were the significant factors in chapter 1 and 2, respectively ( $p<0.05$ for all comparisons). Further analyses including pair-wise comparisons revealed that participants running in OR or ICU were worse than those working at wards and other stations in chapter 1 $(p=0.013$ and $p=0.02$, respectively) and subjects being employed less than 5 years were better than those working more than 15 years in chapter $2(p=0.033)$ (Table 2). After the exclusion of those who refused $(n=11,4.2 \%)$ to answer the related question, participants were evaluated in 2 groups according to their belief of being well-informed ( $n=149,59.1 \%)$ or not $(n=103,40.9 \%)$ on patients' rights. There were significantly less subjects working at OR or ICU, who assumed to have sufficient knowledge $(p<0.05)$, but no other parameters were significant between the groups (Table 3). The points of the participants in both groups were also similar for all chapters and overall questionnaire ( $p>0.05$ for all comparisons) (Table 2). In addition, the rates of getting reported for a rule violation during the last year were also similar within the groups ( $p>0.05)$ (Table 3).

Finally, after the exclusion of the subjects who refused $(n=14)$ to answer related question, it was observed that almost one fifth of all participants $(n=249)$ had been reported for a complaint for violation of a rule related to patients' rights during the last year $(n=49,19.7 \%)$, who 
were significantly more commonly to be among physicians and men ( $p<0.05$ for both) (Table 4). Similarly, participants who were working less than 5 years were more likely to have violation reports, but the comparison did not reach to significance level $(p=0.051)$. When points calculated according to the answers were analyzed, it was observed that participants had violation reports took significantly less points in Chapters 1,3 and 4, and in total ( $p<0.05$ for all comparisons) (Table 2).

\section{Discussion}

It is critically important in ethical and legal perspectives that patients' rights are to be known and associated rules should be followed by professional healthcare givers. The Turkish regulations on patients' rights were prepared according to international texts and published in $1998 .{ }^{1}$ This study includes a questionnaire of 25 questions in
5 chapters based on Turkish Code of Patients' Rights, and aims to assess the level of knowledge of healthcare givers working in a level 3 hospital. In previous studies using the same survey, similar results were shown among physicians working both at level 1 or 3 medical centers. ${ }^{8,9}$ Besides, current study may expose further detailed information in question and chapter basis. Our data have shown that the necessity of patient's consent for medical intervention (Q16) was the most commonly right answered (98\%). This may not be a surprising point, since most of the healthcare givers and takers consider the patient's approval before the intervention as the first step of patients' rights. Similarly, chapter 4, evaluating patients' confirmation on medical intervention was the best known one as chapter 1, assessing the right of benefiting from health services. However, it is a significant outcome that chapter 3 , determining protecting the patient and sickness related information was the least

Table 4: The Relationship between the Evaluated Parameters and Answers of the Subjects on Whether or Not They Were Reported for a Rule Violation Related to Patients' Rights During the Last Year

\begin{tabular}{|c|c|c|c|c|}
\hline & $\begin{array}{l}\text { Believe to Be Sufficient } \\
(\mathrm{n}=252)\end{array}$ & Sufficient $(n=149)$ & Not Sufficient ( $n=103$ ) & $P$ \\
\hline \multirow{2}{*}{ Gender } & Female $(n=199)(\%)$ & $33(16.6)$ & $166(83.4)$ & \multirow{2}{*}{$0.027^{*}$} \\
\hline & Male $(n=50)(\%)$ & $16(32)$ & $34(68)$ & \\
\hline \multirow{2}{*}{ Age } & $<35(n=142)(\%)$ & $31(21.7)$ & $111(78.3)$ & \multirow{2}{*}{$0.206^{*}$} \\
\hline & $>35(n=107)(\%)$ & 18 (16.8) & $89(83.2)$ & \\
\hline \multirow{2}{*}{ Department } & Surgical $(n=142)(\%)$ & $32(22.5)$ & $110(77.5)$ & \multirow{2}{*}{$0.202^{*}$} \\
\hline & Medical $(n=107)(\%)$ & $17(15.9)$ & $90(84.1)$ & \\
\hline \multirow{5}{*}{ Working Station } & ER $(n=35)(\%)$ & $5(14.3)$ & $30(85.7)$ & \multirow{5}{*}{$0.218^{*}$} \\
\hline & Policlinics ( $n=115)(\%)$ & $30(26.1)$ & $85(73.9)$ & \\
\hline & Ward $(n=45)(\%)$ & $6(13.3)$ & $39(86.7)$ & \\
\hline & OR or ICU $(n=23)(\%)$ & $4(17.4)$ & 19 (82.6) & \\
\hline & Other $(n=31)(\%)$ & $4(12.9)$ & $27(87.1)$ & \\
\hline \multirow{3}{*}{ Occupation } & Physician (n=54) (\%) & $23(42.6)$ & $31(57.4)$ & \multirow{3}{*}{$<0.001^{*}$} \\
\hline & Nurse $(n=175)(\%)$ & $25(14.3)$ & $150(85.7)$ & \\
\hline & Other $(n=20)(\%)$ & $1(5)$ & $19(95)$ & \\
\hline \multirow{4}{*}{$\begin{array}{l}\text { Duration of Occupation } \\
\text { (in years) }\end{array}$} & $<5(\mathrm{n}=68)(\%)$ & $21(30.9)$ & $47(69.1)$ & \multirow{4}{*}{$0.051^{*}$} \\
\hline & $5-10(n=41)(\%)$ & $6(14.6)$ & $35(85.4)$ & \\
\hline & $10-15(n=40)(\%)$ & $5(12.5)$ & $35(87.5)$ & \\
\hline & $>15(n=100)(\%)$ & $17(17)$ & $83(83)$ & \\
\hline
\end{tabular}

(ER: Emergency room, OR: Operation room, ICU: Intensive care unit)

* Chi Square test 
known chapter, since healthcare givers may not recognize the importance of patients' privacy. In our opinion, further education on medical professionals may emphasize the importance of patients' confidentiality.

Current study has also assessed the factors effecting the information on patients' rights. None of the evaluated parameters were found to be significant in total sums; however younger participants and those being an employee for less than 5 years took better points from chapter 2, and those working in OR or ICU were worse than others in chapter 1. A previous study by Topbas et al showed that younger physicians were more informed than the older associates on patients' rights. 5 Another survey based analysis on healthcare workers found working less than 5 years as a significant factor..$^{10}$ It was also speculated that these findings might be because there was more instruction on patients' rights in medical schools in recent years compared to the previous ages. ${ }^{5} \mathrm{Ho}-$ wever; our data did not correlate with this finding except chapter 2, which reflects giving adequate information to the patient about his/her medical status. In addition, our results showed that participants working in OR or ICU were worse than others in considering the right of benefitting from health services (Chapter 1). This may be an incidental finding since none of the other comparisons were significant, or may be due to the working conditions of these employees which restricts direct face-toface relation with patients and patients' relatives. We believe that none of the parameters were significant, so all healthcare givers should be under consideration of both during their education or in service courses.

Healthcare givers generally believe that they are wellinformed on patients' rights, but little is known whether or not their beliefs correlated with their information on the subject. ${ }^{10,11,12}$ Current study revealed that almost $60 \%$ of the participants felt themselves well-informed on patients' rights, which was comparable to that disclosed in other analyses that examined the awareness of the healthcare workers in level 1 medical centers. ${ }^{10,13}$ Furthermore, our data also showed that interviewee working at OR or ICU believed that they were less-informed on patients' rights. As explained before, this may be because of their limited self-confidence due to working stations which restrict direct dialogue to the patients and patients' relatives. Most importantly, current study revealed that the level of knowledge in participants who believed that they were well-informed was similar to those felt themselves inadequate in patients' rights; as well as the rates of getting reported for a rule violation during the last year were also comparable within the two groups. This is a significant finding proving that even those who suppose themselves to be better informed on the subject may not be that way, and deserve to join in further education and courses as other healthcare workers. Finally, current study investigated the reports for a rule violation related to patients' rights. It showed that almost $20 \%$ of participants confess to have been reported during the last year, and males and physicians had more risk for having violation reports than females and nurses or other workers. The comparisons of the points taken from chapters and in sum revealed that participants, who had more violation reports, were significantly lessinformed than those who were not reported during the last year. This calculation is particularly important, since having a violation report is the one and only significant factor affecting the level of sum points in our study, which shows that less awareness may cause more violation reports. Thus, since violation reports were directly related to the information level and effect nearly one fifth of all healthcare workers who have at least one report in a yearly period, we believe that these data may be shared with the healthcare workers in order to alarm them about the importance of the patients' rights.

As conclusion; current study revealed no significant predicting parameter related to the awareness of healthcare givers on patients' rights. Healthcare givers, who believe that they are well-informed, may not be that way. Violation reports were not rare, and were directly related to the level of information on patients' rights. This is particularly true for physicians and males who have more violation reports. Thus, educations are better to be continued among all workers without any exceptions. 


\section{References}

1. Code of Patient Rights. Official Journal of Turkish Republic 1998;23,420:1

2. Kennedy MC. Clinical trials without consent: Some experiments simply cannot be done. Med J Aust 2002;177:40-42.

3. Elcioglu O, Demirhan AE. Klinik uygulamalarda her durumda ortaya cikan etik yukumlulukler. In: Demirhan AE, Oguz Y, Elcioglu O, Dogan H (Eds). Klinik Etik. İstanbul. Nobel Tıp Kitabevi; 2001. pp.104-48.

4. Nisancı Y, Nazlı N, Ozkan M, Ozcan M. Ethics and Medicine, Turkish Society of Cardiology 2009; 37:1-2.

5. Topbas M, Ozlu T, Can G, Bostan S. How Much Doctors Know About Patient's Rights? Knowledge Level Of Residents And Interns In A Medical School, Türkiye Klinikleri J Med Ethics 2005; 13:81-85

6. Oguz NY. The Developments In Patients' Rights And Changing Values. T Klin J Med Ethics 1997;5:50-55.

7. http://www.tbmm.gov.tr/komisyon/insanhaklari/belge/um sagliktesislerindehastahaklari.pdf (accessed 10 August 2010).

8. Yurumez Y, Cevik T, Yavuz Y, Do we Know The Rights of Patients? Journal of Academic Emergency Medicine 2010;2:67-71.

9. Ozer A, Gunay O.Knowledge levels of physicians working in Kayseri on patient rights, Erciyes Medical Journal 2007; 29(1):5663.

10. Ocaktan E, Yıldız A, Ozdemir O. Knowledge and attitudes of health care personal Working At Abidinpasa Health Group Directorate, Journal Of Medical University Faculty Of Medicine 2004; 57(3): 129-137.

11. Woogara J. Patient's Right To Privacy And Dignity In The NHS Nurs Stand 2005; 19.33-37.

12. Duran Ö, Yıldırım G, Gercek S. Knowledge levels of State Hospital Staff about patient rights Sted. 2008;17(1),1-6.

13. Zincir H, Erten ZK. Knowledge levels of the health care employees working at the primary health institutions about patient rights, International Journal of Human Sciences, 2009; 6 (1): 877-885. 